\title{
Survival of Stenocarpella maydis on Corn Residue in Indiana
}

\author{
Martha P. Romero Luna, Department of Plant Pathology, James J. Camberato, Department of Agronomy, and Kiersten A. Wise, \\ Department of Plant Pathology, Purdue University, West Lafayette, IN 47907
}

Accepted for publication 14 March 2017.

\begin{tabular}{|c|c|}
\hline \multicolumn{2}{|c|}{ Abstract } \\
\hline $\begin{array}{l}\text { Diplodia ear rot (DER), caused by the fungus Stenocarpella maydis, } \\
\text { has become a prevalent corn disease in the Midwest. The survival } \\
\text { of } S \text {. maydis on corn kernels and stalks was evaluated in Tippecanoe, } \\
\text { Co., Indiana, over } 17 \text { months. Infested corn residue was either left } \\
\text { on the soil surface or buried at } 10 \text { or } 20 \mathrm{~cm} \text {. Survival of } S \text {. maydis } \\
\text { was determined by observing the presence of pycnidia per unit } \\
\text { of corn residue under a stereomicroscope and by assessing } \\
\text { conidia viability by evaluating germination. Months of environ- } \\
\text { mental exposure and soil depth affected S. maydis survival. }\end{array}$ & $\begin{array}{l}\text { Pycnidia production and conidia germination were observed up } \\
\text { to } 11 \text { months on corn kernels and } 17 \text { months on corn stalks when } \\
\text { left on the soil surface. Minimal or no conidia germination of } \\
\text { S. maydis was observed on residue recovered from } 10 \text { or } 20 \mathrm{~cm} \\
\text { after } 4 \text { months on kernels and } 7 \text { months on stalks. These results } \\
\text { demonstrate that surface corn residue can be a long-term source of } \\
\text { inoculum and at least two years of rotation to a nonhost crop or } \\
\text { residue removal through tillage may be necessary to reduce po- } \\
\text { tential initial inoculum. }\end{array}$ \\
\hline
\end{tabular}

Corn yield is influenced by many factors, including weather, pests, and management practices (Thomison et al. 2005). Many pathogens can infect corn (White 1999) and among the resulting diseases, ear rots are some of the most important. Ear rot diseases occur wherever corn is produced, reducing yield and compromising grain quality (White 1999). Diplodia ear rot (DER), a monocyclic disease caused by the fungus Stenocarpella maydis (Berk.) B. Sutton, is a predominant ear rot in the Midwest (Rossouw et al. 2009; White 1999). Mueller and Wise (2012, 2013) reported a combined yield loss for 2012 and 2013 of approximately 1.36 million metric tons for 22 states in the United States and one province in Ontario. In 2014, yield loss due to DER increased to 17 million metric tons (Mueller and Wise 2014).

Planting resistant hybrids is the most reliable way to control DER (Hooker 1956; Klapproth and Hawk 1991); however, no current hybrid is completely resistant to the disease (Rossouw et al. 2009). Stenocarpella maydis is a residue-born pathogen, and its spread is limited by the proximity of the corn plants to the inoculum. Thus, rotation with any other crop could potentially reduce inoculum prevalence (Flett 1993; Sutton and Waterston 1966; Ullstrup 1970). Flett et al. (2001) evaluated DER incidence under different crop rotation systems and observed that wheat (Triticum spp.), soybean (Glycine max L. Merril), and peanut (Arachis hypogaea L.) reduced DER when rotated with corn.

Tillage is also often recommended for DER control and several studies in South Africa determined that the most effective management practice to control DER was complete burial of corn residue after each corn crop by moldboard plowing (Flett et al. 1998; Flett and Wehner 1991). This tillage practice reduces residue and subsequently inoculum for the following crop. However, in Indiana, tillage practices are much less aggressive than moldboard plowing, and many farmers use no-tillage, strip-tillage, or chiselplow forms of tillage that leave 30 to $90 \%$ of the previous crop's

Corresponding author: K. Wise; E-mail: kawise@purdue.edu

(c) 2017 The American Phytopathological Society residue on the field (Franzmeier and Steinhardt 2001; ISDA 2015). Therefore, a substantial amount of residue remains in a field, and the efficacy of crop rotation and tillage methods for disease control will be influenced by the length of time the pathogen can survive on residue. Flett et al. (1992) determined that $S$. maydis was able to survive on surface residue for almost 11 months in South Africa and determined there was a positive linear relationship between amount of residue and DER incidence. Casa et al. (2003) determined S. maydis survives for 12 months on residue in Brazil. However, the survival period of the fungus has yet to be determined in the United States, and it is not known if the results from survival studies conducted in a semitropical climate will be applicable to the midwestern United States. Average winter temperatures in South Africa are 6 to $20^{\circ} \mathrm{C}$ (Behnin 2006) and 9 to $12^{\circ} \mathrm{C}$ in Brazil (http://en.climate-data.org) compared with -10 to $-1{ }^{\circ} \mathrm{C}$ in the Midwest (Kunkel et al. 2013). Research on the biology of $S$. maydis has demonstrated that ideal conditions for conidia germination under in vitro conditions are temperatures between 27 and $30^{\circ} \mathrm{C}$ under a 12-h light:dark cycle (Kuhnem Júnior et al. 2012; Starzyk 1976). However, it is unknown how germination is affected by field conditions and what the impact of these conditions are on the viability and longevity of $S$. maydis. The objective of this study was to determine the survival period of S. maydis on corn stalk and kernel residue at different soil depths in a corn field in Indiana.

\section{Corn Tissue Collection and Placement in Field Trials}

Corn ears and stalks from a commercial corn hybrid (P34F97, Pioneer Hi-Bred International, Inc., Des Moines, IA) were handharvested in 2014 from the Northeast Purdue Agricultural Center (NEPAC) Whitley Co., IN, at milk stage (R3) (Abendroth et al. 2011) to establish survival of $S$. maydis. Ears were shelled and stalks were cut into 8- to 22-cm sections, consisting of one node and one complete internode. Kernels and stalks were placed into clear autoclave bags $(60.96 \times 76.2 \mathrm{~cm})$, with 1 liter of deionized water. Each bag contained either 100 stalk pieces or 800 kernels, was soaked for $12 \mathrm{~h}$ then autoclaved for $1 \mathrm{~h}$, allowed to cool, and 
autoclaved for an additional hour. After sterilization, bagged stalks and kernels were inoculated with $13 \mathrm{mg}$ of wet mycelium from a single isolate of $S$. maydis, and incubated at $28^{\circ} \mathrm{C}$ until fully colonized (approximately 15 days). Pure cultures were obtained from ears naturally infected with S. maydis at the Agronomy Center for Research and Education (ACRE) in Tippecanoe Co., IN, and were grown for 15 days on natural oatmeal media (NOA) (Romero Luna 2012). Pure cultures were prepared and stored prior to inoculation as described in Romero and Wise (2015).

Colonized tissue was mixed and arbitrarily separated into sets containing 50 kernels and 5 stalk pieces to be placed in bags for the experiment. All colonized kernels and stalk pieces were separately weighed and air-dried in the greenhouse for 7 days. Dried weights and fungal colonization ratings were recorded. The average dried weight was $10 \mathrm{~g}$ for kernels and $23 \mathrm{~g}$ for stalks. Kernels and stalks were rated to determine the level of $S$. maydis colonization prior to starting the experiment. Ratings were based on percentage of mycelia covering the tissue and pith degradation (Romero Luna 2016). Dried and rated stalk tissue (5 pieces) was placed in $24 \times$ 26-cm charcoal fiberglass bags (New York Wire, Hanover, PA), and 50 kernels were placed in similar bags sized $9 \times 11 \mathrm{~cm}$, and then both bags were placed in $28.5 \times 29$-cm aluminum screening bags (New York Wire, Hanover, PA). Bags were stored at $4^{\circ} \mathrm{C}$ until buried. Final tissue weights were recorded again before bags were placed in the field.

\section{Field Description and Experiment Design}

The field experiment was established in November 2014 at the Agronomy Center for Research and Education (ACRE) in Tippecanoe Co., IN. The experimental design was a split-plot with four replications, where the whole plot was residue burial depth (surface (0), 10, and $20 \mathrm{~cm}$ ). Subplots were sampling times of 4, 7, and 11 months after burial, and monthly until 17 months after initial placement, for a total of nine sampling times. An experimental unit was a single plot. Plots were $9 \mathrm{~m}$ long, and divided and marked every $3 \mathrm{~m}$ where bags were buried. Treatments were replicated 4 times in the experiment, and each replication contained a sample for each sampling time at each burial depth. Bags were laid flat to ensure that bagged tissue had equal soil exposure. Pins with dimensions of $15.24 \times 2.54 \times 15.24 \mathrm{~cm}$ (DeWitt, Sikeston, MO) were used to anchor bags to the soil surface or when buried. Watchdog 1000 series temperature and moisture sensors were placed within the experiment above the soil surface (Watchdog Spectrum Technologies Inc., Plainfield, IL), and Decagon 5TM digital soil sensors (Decagon Devices Inc., Pullman, WA) were placed at the soil surface, 10 , and $20 \mathrm{~cm}$ below the soil surface at 5 different locations in the trial. All sensors recorded data every $30 \mathrm{~min}$ for the duration of the experiment.

\section{Determining Stenocarpella maydis Survival on Residue}

On the day of experiment establishment in the field, a sample of stalks and kernels was processed to assess initial pycnidia production and germination percentage of $S$. maydis on corn tissue. At each subsequent sampling time, one bag of each residue burial depth from each replicate was retrieved. Tissue from each residue burial depth was removed from each bag, brushed to remove adhered soil, weighed, and air-dried in the greenhouse for 7 days. Dried tissue was weighed again, surface disinfested with $5 \%$ sodium hypochlorite and Tween 20 (Biorad Laboratories, Hercules, CA) for $1 \mathrm{~min}$, rinsed twice with distilled water, and then dried for $4 \mathrm{~h}$. A total of 3 nodes from stalk tissue and 27 kernels were arbitrarily chosen per replication and processed, incubated, and analyzed for each burial depth at each sampling time. Nodes were cut in half, placed on NOA in a $100 \times 15-\mathrm{mm}$ petri dish, and incubated for 15 days under $12: 12$ light:dark cycles at $28^{\circ} \mathrm{C}$. Kernels were placed on NOA and incubated for 10 days under the same conditions. After each incubation period, nodes and kernels were examined for $S$. maydis pycnidia presence under a dissecting microscope $(7.6 \times$ magnification). Formation of dark-brown to black pycnidia indicated presence of $S$. maydis, which was confirmed based upon microscopic examination of conidia first under $100 \times$ magnification followed by $200 \times$. Conidial characteristics included a pale-brown conidium, narrowly ellipsoid, straight or curved, with 0 to 2 septa. Corn tissue that had pycnidia but no conidia were assigned a ' + '. If conidia were present in the pycnidia, a ' ++ ' was assigned. Tissue with no pycnidia were given a '-' rating.

Viability of recovered $S$. maydis was determined by assessing conidial germination. After pycnidia presence was confirmed, three pycnidia from each node, and nine pycnidia from the 27 kernels were hand-picked with a sterile needle and each placed separately into a 1.5-ml disposable microcentrifuge tube (VWR International, Radnor, PA) with $50 \mu \mathrm{l}$ of $\mathrm{dH}_{2} \mathrm{O}$. This step was repeated for each burial depth at each replication. Each suspension was agitated and pipetted onto a water agar plate containing $20 \mathrm{~g}$ of Bacto Agar (Becton, Dickinson and Co., Sparks, MD) per liter, and spread with a Petri disposable L-shaped spreader (USA Scientific, Ocala, FL). Plates were incubated at room temperature for $24 \mathrm{~h}$ in the dark. Plates were then observed for germination of 100 conidia in several arbitrarily selected fields of view using a dissecting microscope $(6 \times$ magnification). A conidium was considered to have germinated if the length of the germ tube was at least as long as the conidium (Romero Luna and Wise 2015). For each sample where conidia germinated, a ' +++ ' rating was assigned.

\section{Pathogenicity of Recovered Stenocarpella maydis Isolates}

Residue samples that produced viable conidia were tested to determine if pathogenicity was affected by burial depth or time. Two pure cultures of $S$. maydis per sample for each burial depth were obtained when possible. Isolates were placed in long-term storage after collection, following a previously established protocol (Romero and Wise 2015). Pathogenicity tests were conducted within three months after isolation. Ears of the corn hybrid P34F97 were hand-harvested in 2015 from NEPAC, and inoculated at milk stage (R3) (Abendroth et al. 2011) with a suspension of $1 \times 10^{6}$ conidia/ml from the selected culture (23 days old) of $S$. maydis growing on NOA following Kim and Woloshuk (2011). The inoculation protocol consisted of cleaning the corn ears by pulling back the husk and removing the silk. Ears were wound-inoculated with a pin-bar that was dipped into the conidia suspension. The pinbar contained 18 pins and the resulting wound was $0.5-\mathrm{cm}$ depth. A water control was included, in which an ear was wounded but not inoculated with $S$. maydis. Three ears were inoculated per isolate. After inoculation, each ear was individually covered with a clear plastic bag and placed for $24 \mathrm{~h}$ in the greenhouse. After this period, plastic bags were opened to avoid moisture accumulation. Ears were maintained in the greenhouse at $24^{\circ} \mathrm{C}$ for 10 days, and then visually evaluated for signs of DER. Isolates were considered pathogenic if white mycelium representative of $S$. maydis was observed on the wound-inoculated kernels. Brown discoloration of the kernels and cob, and pycnidia presence were also observed and recorded.

\section{Data Collection and Statistical Analysis}

Conidial germination occurred mainly on tissue retrieved from the soil surface, therefore only data obtained from the soil surface 
was used to determine the effect of tissue and sampling time on S. maydis survival. Because conidial germination was observed from stalk tissue retrieved after four and seven months from the soil surface and $10-\mathrm{cm}$ burial depth, an additional analysis was performed where a pairwise comparison analysis (TTEST) in SAS 9.4 (SAS Institute Inc., Cary, NC) was conducted to determine if burial depth significantly affected survival.

Conidial germination percentage of $S$. maydis were tested for normality using PROC UNIVARIATE in SAS 9.4, and transformed (arcsine-square-root transformed) to meet normality assumptions. Back-transformed means were presented after analysis. Conidial germination percentages data were subjected to analysis of variance (PROC GLIMMIX) in SAS 9.4 to detect any effect of sampling time, tissue, and their interactions on $S$. maydis survival, as well as the influence of soil moisture and soil temperature on $S$. maydis survival at each burial depth. Replications were considered random effects, while sampling time, tissue, soil moisture, and soil temperature were considered fixed effects. Means were compared using least-square means (LS) test at the $P \leq 0.05$ level.

\section{Stenocarpella maydis Survival on Residue}

Average monthly air temperatures at the field site at ACRE from November 2014 to April 2016 are presented in Figure 1. Average monthly soil temperature and soil moisture at the three burial depths of surface (0), 10, and $20 \mathrm{~cm}$ are presented in Table 1. During the months of November 2014 to February 2015 and October 2015 to March 2016, average soil surface $(0 \mathrm{~cm})$ temperatures were generally colder (within $1.5^{\circ} \mathrm{C}$ ) than soil temperatures at 10 and $20 \mathrm{~cm}$. Warmer temperatures (within $1.5^{\circ} \mathrm{C}$ ) were observed from March 2015 to September 2015, and in April 2016 at the soil surface $(0 \mathrm{~cm})$ compared with 10 and $20 \mathrm{~cm}$. Average percent soil moisture at the soil surface $(0 \mathrm{~cm})$ was generally 1 to $4 \%$ drier than at $10 \mathrm{~cm}$ and 1 to $12 \%$ drier than at $20 \mathrm{~cm}$ (Table 1) except in January, February, and March 2015, and March and April 2016 where the soil surface $(0 \mathrm{~cm})$ was 1 to $2 \%$ wetter than at $10 \mathrm{~cm}$.

Pycnidia and conidia of $S$. maydis were observed on residue left at the soil surface after $4,7,11,12$, and 14 months on kernels and stalks and until month 17 on stalks (Table 2). Pycnidia were observed on kernels buried at $10 \mathrm{~cm}$ up to 11 months; however, no conidia were detected within these pycnidia when viewed under the microscope. Pycnidia were not observed from kernels buried at $20 \mathrm{~cm}$ at 4 months, the first sampling date after the experiment was
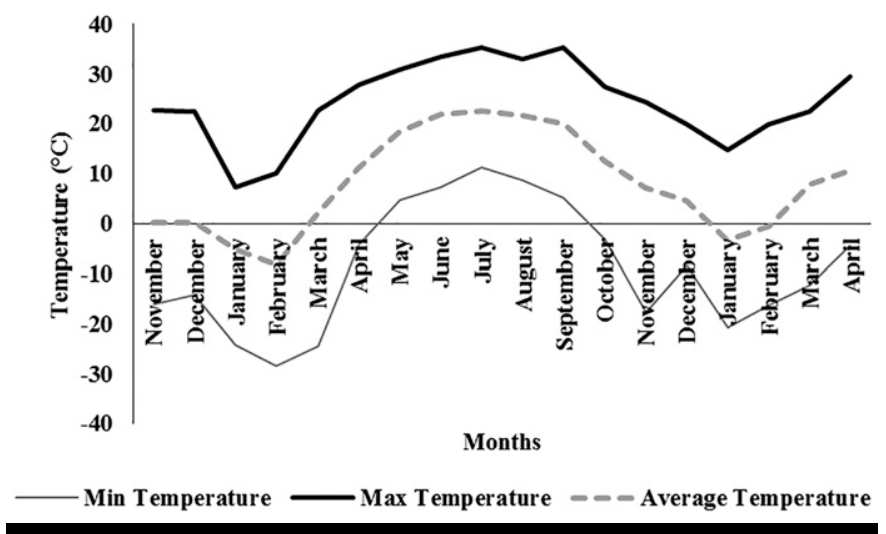

FIGURE 1

Minimum (min), maximum (max), and average air temperatures $\left({ }^{\circ} \mathrm{C}\right.$ ) collected every 30 minutes with Watchdog 1000 series loggers from November 2014 to April 2016 in Tippecanoe Co., IN. initiated. After 12 months, corn kernels had decomposed fully at 10and $20-\mathrm{cm}$ depths. Stalks buried at 10 and $20 \mathrm{~cm}$ produced pycnidia at 7 months, but no conidia were detected on stalks buried at $10 \mathrm{~cm}$. After 11 months, pycnidia were not observed on stalks buried at 10 or $20 \mathrm{~cm}$ (Table 2). Because no pycnidia were detected after 11 months on corn stalks buried at 10 and $20 \mathrm{~cm}$, samples retrieved after 12 months from these burial depths were not assessed for S. maydis survival.

Survival of $S$. maydis was determined by the ability of conidia to germinate after being retrieved from the field at the soil surface after $4,7,11$, and consecutive months until month 17 . The tissue type (kernel versus stalk) did not significantly affect $S$. maydis survival $(P=0.8853)$. Therefore, data from corn kernels and stalks were analyzed together. Sampling time significantly affected conidial germination $(P<0.0001)$. Germination was significantly higher at the beginning of the experiment compared with germination observed at later sampling times. Stenocarpella maydis germination significantly declined after 11 months; however, except for month 12 where no germination was observed, $S$. maydis remained viable with a germination percentage between 21 and $30 \%$ up to month 17 . Soil temperature and soil moisture fluctuated across the experiment (Table 3), and when soil moisture and soil temperature were analyzed together to determine their effect on $S$. maydis survival, we observed that soil conditions significantly reduced $S$. maydis survival $(P<0.0001)$.

Based on the pairwise comparison analysis, significantly higher conidia germination percentages were observed at 4 and 7 months from stalks retrieved from the soil surface $(0 \mathrm{~cm})$ compared with stalks retrieved from $10-\mathrm{cm}$ burial depth $(P=0.0456)$. Conidia germination percentage declined after 7 months of exposure to field conditions (Table 3).

Pathogenicity of recovered $\mathbf{S}$. maydis isolates. Stenocarpella maydis isolates were obtained only from corn kernels and stalks recovered after 4 months from the soil surface $(0 \mathrm{~cm})$ and $10 \mathrm{~cm}$, and from kernels and stalks recovered from the soil surface after 7 months. Pathogenicity was confirmed from these isolates based on disease symptoms and signs such as white mycelium representative of $S$. maydis, brown discoloration of kernels and cob, and pycnidia presence on and within kernels. Control (waterinoculated) ears exhibited a slight discoloration on the inoculated kernels due to the wound. However, control ears did not exhibit any mycelial growth or discoloration consistent with infection of S. maydis (Fig. 2). Although conidia were observed on samples collected from the soil surface up to 17 months, attempts to recover viable isolates after 7 months were unsuccessful.

\section{Influence of S. maydis Survival on Disease Management}

Our findings indicate that $S$. maydis continues to produce conidia capable of germinating on corn residue on the soil surface for at least 17 months in Indiana. Based on the winter temperatures that occur in Indiana, we predicted that $S$. maydis survival would be comparable with other $S$. maydis survival studies in South Africa and Brazil by Flett et al. (1992) and Casa et al. (2003), which reported survival periods of 11 and 12 months, respectively. However, our findings indicate that the survival period of $S$. maydis is longer than those previously reported outside of the United States, implying that the winter environmental conditions in Indiana might prolong survival. Although specific environmental conditions were not reported for the previous $S$. maydis survival studies, both studies were conducted under subtropical environments where high temperatures and soil moisture occurred. Environmental factors such as temperature and rainfall have an important influence on fungal 
TABLE 1

Mean monthly temperatures and soil moisture at the soil surface $(0 \mathrm{~cm})$, and at $10-$ and $20-\mathrm{cm}$ soil depths at the experimental site located in Tippecanoe Co., IN, where Stenocarpella maydis survival on corn residue was evaluated

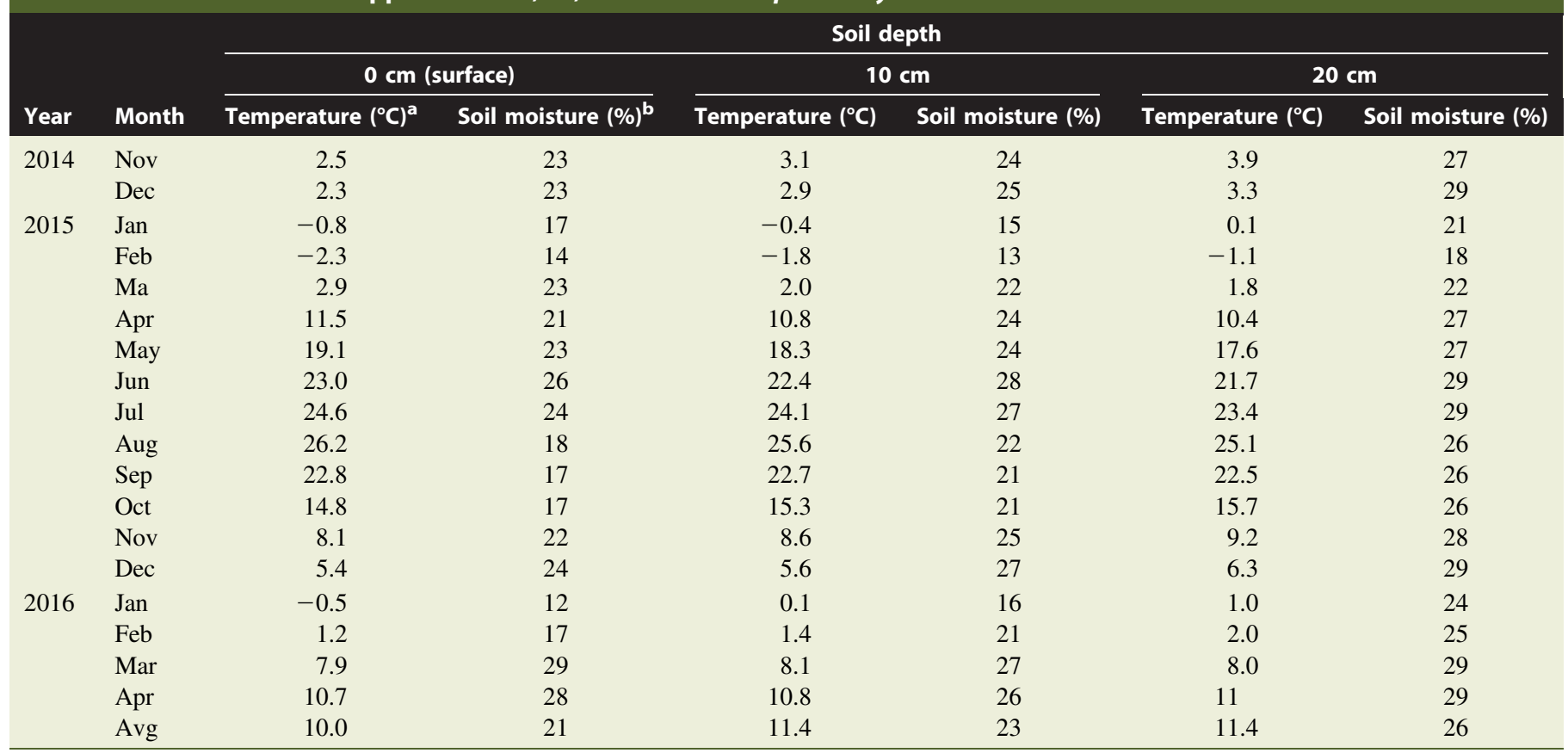

${ }^{\text {a }}$ Temperature was recorded every 30 min with a Decagon 5TM digital soil sensor.

${ }^{\mathrm{b}}$ Soil moisture was recorded every $30 \mathrm{~min}$ with a Decagon 5TM digital soil sensor.

\begin{tabular}{|c|c|c|c|c|c|c|c|c|c|c|c|}
\hline \multirow{2}{*}{ Corn residue type } & \multirow{2}{*}{ Burial depth $(\mathrm{cm})$} & $\begin{array}{l}\text { conidia } \\
\text { ampling }\end{array}$ & $\begin{array}{l}\text { ducti } \\
\text { es fre }\end{array}$ & $\begin{array}{l}\text { TABLE } \\
\text { on co } \\
\text { March }\end{array}$ & $\begin{array}{l}\text { esidu } \\
15 \text { (4 }\end{array}$ & $\begin{array}{l}\text { olace } \\
\text { onth }\end{array}$ & $\begin{array}{l}\text { field } \\
\text { o April }\end{array}$ & $\begin{array}{l}\text { perime } \\
\text { b16 (1) }\end{array}$ & $\begin{array}{l}\text { in No } \\
\text { lonth }\end{array}$ & aber & \\
\hline & & \multicolumn{10}{|c|}{ Sampling time (months) ${ }^{\mathrm{a}}$} \\
\hline \multirow{2}{*}{ Kernels } & 0 (surface) & $+++^{\mathrm{c}}$ & +++ & +++ & +++ & ++ & - & ++ & - & NS & NS \\
\hline & 10 & +++ & - & - & + & $\mathrm{NA}^{\mathrm{d}}$ & NA & NA & NA & NA & NA \\
\hline \multirow{2}{*}{ Stalks } & 10 & +++ & +++ & +++ & - & $\mathrm{NS}^{\mathrm{e}}$ & NS & NS & NS & NS & NS \\
\hline & 20 & +++ & - & + & - & NS & NS & NS & NS & NS & NS \\
\hline
\end{tabular}

${ }^{\text {a }}$ Sampling time is expressed as months after experiment was initiated.

${ }^{\mathrm{b}}$ Sampling set that was processed the same day that the experiment was initiated.

${ }^{\mathrm{c}}$ Rating scale: $+++=$ conidia germinated; $++=$ pycnidia with conidia; $+=$ pycnidia but no conidia; $-=$ no pycnidia observed.

${ }^{\mathrm{d}} \mathrm{NA}=$ no kernels were recovered after 12 months the experiment was initiated.

${ }^{\mathrm{e}} \mathrm{NS}=$ samples not assessed because no pycnidia were observed beyond 11 months.

growth, reproduction, and survival (Lynne 2015). In our study, $S$. maydis survival on soil-surface residue declined substantially after 7 months, which corresponds to June of 2015, one of the wettest months reported in Indiana since 1895 (Scheeringa and Mangan 2015). This extreme increase in moisture seems to have reduced the viability of $S$. maydis. A similar decline in $S$. maydis survival was observed by Flett et al. (1992) when unusual spring rains occurred during their study.

Surface crop residue has previously been identified as a primary source of S. maydis inoculum. Flett and Wehner (1991) and Flett et al. (1998) identified a positive linear relationship between surface corn residue and $S$. maydis incidence, and crop residue has also been identified as a potential inoculum source in other corn plant pathosystems such as: Colletotrichum graminicola, causing anthracnose leaf blight and stalk rot (Lipps 1985); Cercospora zeaemaydis, causing gray leaf spot (De Nazareno et al. 1992; Payne and Waldron 1983); and Fusarium spp., causing Fusarium stalk rot (Cotten and Munkvold 1998), among others. Therefore, the burial depths in our study were included to mimic the practice of a chiselplow or disc-tillage system where crop residue is incorporated into the soil surface. We observed that burial depth influenced survival of $S$. maydis, and conidia germination decreased significantly when corn residue was buried at 10 - and 20-cm depth compared with corn residue remaining at the soil surface. Although our findings indicate that tillage could be implemented as a measure to reduce potential inoculum, residue may need to be completely buried since stalk residue left on the surface decomposes slowly (Coyne 1999; Schwietzke et al. 2009). Many farmers in Indiana use tillage 
systems such as chisel or disc tillage that leave at least $30 \%$ of the previous crop residue on the soil surface (Bredford and Peterson 2000). In these production systems, farmers should consider rotating away from corn for two years since our research indicates that

\begin{tabular}{cccc}
\multicolumn{5}{c}{ TABLE 3} \\
Effect of soil moisture and temperature on viability of \\
Stenocarpella maydis conidia, expressed as germination \\
percentage. Experiment was established in Tippecanoe Co., \\
IN, and initiated in November $\begin{array}{c}\text { 2014 } \\
\text { (month }\end{array}$
\end{tabular}

${ }^{\text {a }}$ Sampling time expressed as months after experiment initiation.

${ }^{b}$ Values represent the accumulated average of soil temperature or soil moisture at the time of sampling.

${ }^{c}$ Values with the same letter are not significantly different based on leastsquare means (LS) test $(P \leq 0.05)$.
$S$. maydis would still be viable even after a one-year rotation away from corn.

In our study, it was difficult to obtain pure cultures of $S$. maydis after 7 months, even though viable conidia were observed up to 17 months. It is possible that after being under adverse environmental conditions, the nutrients provided in the NOA media were not enough to supply the fungus with the required nutrients to continue with vegetative growth after germination. Therefore, we were only able to confirm pathogenicity of isolates collected up to 7 months. Future pathogenicity studies on S. maydis could use techniques that disrupt fungal spore dormancy such as the use of glass beads (Van Etten and Freer 1978), exposure to high or low temperatures, cycles of wetting and drying or by the use of specific chemicals (Isaac 1992).

After 12 months (November 2015), S. maydis pycnidia were present on samples collected from the soil surface, but conidia germination was not observed. However, conidia obtained from samples collected from the surface at the next sampling time (13 months) germinated, and conidia collected up to 17 months germinated as well. We hypothesize that environmental conditions between months 11 and 12 influenced germination in samples collected at month 12. October 2015 (month 11) was hot and dry followed by warm and wet conditions in November 2015 (month 12) (Scheeringa and Mangan 2015). This abrupt change in moisture may have influenced the ability of $S$. maydis to produce conidia capable of germinating. The effect of environment on production of fungal structures of other ear rot pathogens has been previously reported. Inch and Gilbert (2003) and Pereyra et al. (2004) observed

\section{A}

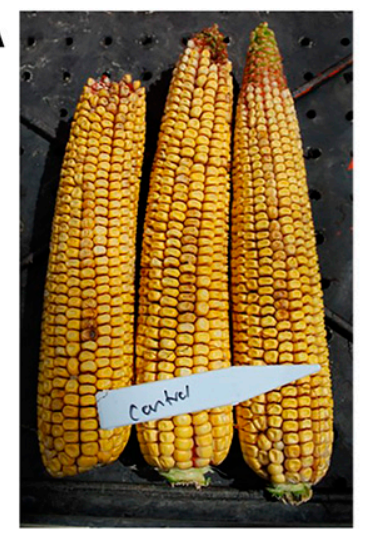

B
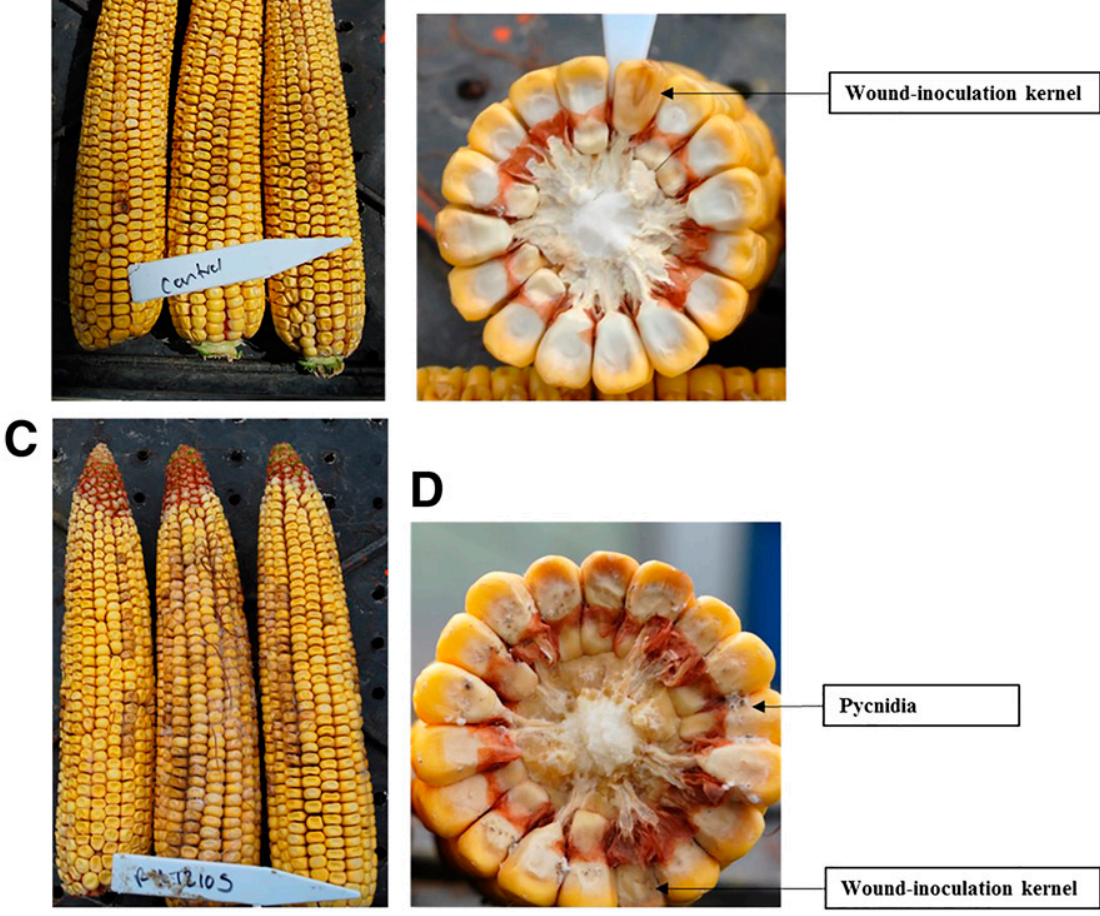

D

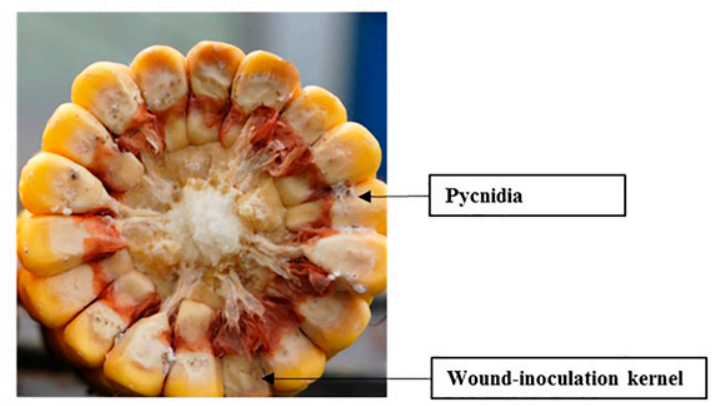

\section{FIGURE 2}

Pathogenicity test on Stenocarpella maydis isolates obtained from retrieved corn tissue. Control (water-inoculated) ears (A) and kernels (B) showing a slight discoloration where the pin-bar was inserted. No white mycelium or pycnidia representative of Stenocarpella maydis was observed. Inoculated ears (C) showing brown discoloration on kernels beyond the inoculated area, and white mycelium representative of Stenocarpella maydis and pycnidia on kernels (D) beyond the inoculation site. 
that Gibberella zeae produced perithecia with no ascospores in certain months of the year. Production of perithecia occurred under particular temperature ranges, and temperature had the greatest influence on ascospore development. Cotton and Munkvold (1998) also observed that the proportion of Fusarium spp. recovered fluctuated through a survival experiment.

A single corn hybrid (P34F97) was used for this study to determine the survival period of $S$. maydis. Hybrid decomposition rates may be influenced by hybrid genetics and agronomic characteristics, influencing long-term pathogen survival. Future research examining multiple commercial hybrids could help determine how hybrid characteristics influence $S$. maydis survival. Additional research is also necessary for the better understanding of the mechanisms that influence $S$. maydis pycnidia production and conidial germination, as well as how factors such as light, temperature, and moisture influence its survival on corn residue.

\section{Acknowledgments}

We gratefully acknowledge the financial support of the Indiana Corn Marketing Council. We thank J. Ravellette for technical assistance; N. Anderson, A. Freije, and K. Gans for help in collecting samples; and M. Aime for valuable suggestions on improving this manuscript.

\section{Literature Cited}

Abendroth, L. J., Elmore, R. W., Boyer, M. J., and Marlay, S. K. 2011. Corn Growth and Development. Coop Ext. Pub. PM R 1009. Iowa State Univ., Ames, IA.

Behnin, J. K. 2006. Climate change and South African agriculture: Impacts and adaptation options. Ph.D. diss. University of Pretoria, Pretoria, South Africa.

Bredford, J. M., and Peterson, G. A. 2000. Conservation tillage. Pages G247-G270 in: Handbook of Soil Science. M. E. Summer, ed. CRC Press, Boca Raton, FL.

Casa, R. T., Reis, E. M., and Zambolim, L. 2003. Decomposição dos restos culturais do milho e sobrevivência saprofítica de Stenocarpella macrospora e S. maydis. Fitopatol. Bras. 28:355-361.

Cotten, T. K., and Munkvold, G. P. 1998. Survival of Fusarium moniliforme, $F$. proliferatum, and $F$. subglutinans in maize stalk residue. Phytopathology 88:550-555.

Coyne, M. 1999. Soil Microbiology: An Explanatory Approach, 1st Ed. Delmar Publishers, Albany, NY.

De Nazareno, N. R. X., Lipps, P. E., and Madden, L. V. 1992. Survival of Cercospora zeae-maydis in corn residue in Ohio. Plant Dis. 76:560-563.

Flett, B. C. 1993. Crop plants as host and non-host of Stenocarpella maydis. Phytophylactica 23:237-238.

Flett, B. C., McLaren, N. W., and Wehner, F. C. 1998. Incidence of ear rot pathogens under alternating corn tillage practices. Plant Dis. 82:781-784.

Flett, B. C., McLaren, N. W., and Wehner, F. C. 2001. Incidence of Stenocarpella maydis ear rot of corn under crop rotation systems. Plant Dis. 85: 92-94.

Flett, B. C., and Wehner, F. C. 1991. Incidence of Stenocarpella and Fusarium cob rots in monoculture maize under different tillage systems. J. Phytopathol. 133:327-333.

Flett, B. C., Wehner, F. C., and Smith, M. F. 1992. Relationship between maize stubble placement in soil and survival of Stenocarpella-maydis (Diplodiamaydis). J. Phytopathol. 134:33-38.

Franzmeier, D. P., and Steinhardt, G. C. 2001. Indiana soils: Evaluation and conservation. Coop. Ext. Pub. No. ID-72. Purdue Univ., West Lafayette, IN.

Hooker, A. L. 1956. Association of resistance to several seedling, root, stalk, and ear diseases in corn. Phytopathology 46:379-384.

Inch, S. A., and Gilbert, J. 2003. Survival of Gibberella zeae in Fusarium-damaged wheat kernels. Plant Dis. 87:282-287.

ISDA. 2015. Indiana statewide tillage: 1990-2015. Indiana State Dept. of Agr. (ISDA), Indianapolis, IN. http://www.in.gov/isda/files/No_Till_Trends_19902015_Statewide.pdf
Isaac, S. 1992. Fungal morphogenesis and physiology. Pages 10-69 in: FungalPlant Interactions. Chapman and Hall, London, UK.

Kim, H., and Woloshuk, C. P. 2011. Functional characterization of $f$ st 1 in Fusarium verticillioides during colonization of maize kernels. Mol. PlantMicrobe Interac. 24:18-24.

Klapproth, J. C., and Hawk, J. A. 1991. Evaluation of four inoculation techniques for infecting corn ears with Stenocarpella maydis. Plant Dis. 75: 1057-1059.

Kuhnem Júnior, P. R., Casa, R. T., Bogo, A., Agostineto, L., Bolzan, J. M., and Miqueluti, D. J. 2012. Effects of temperature, light regime and substrates on the production and germination of Stenocarpella maydis pycnidiospores. Acta Sci. Agron. 34:11-16.

Kunkel, K. E., Stevens, L. E., Sun, L., Janssen, E., Wuebbles, S. D., Hilberg, M. S., Tim-lin, L., Westcott, N. E., and Dobson, J. G. 2013. Regional climate trends and scenarios for the U.S. National Climate Assessment. Part 3. Climate of the Midwest U.S. NOAA Tech. Report NESDIS 142-3. U.S. Dept. of Commerce, Washington, DC. https://scenarios.globalchange.gov/sites/default/ files/NOAA_NESDIS_Tech_Report_142-3-Climate_of_the_Midwest_U.S_0.pdf.

Lipps, P. E. 1985. Influence of inoculum from buried and surface corn residues on the incidence of corn anthracnose. Phytopathology 75:1212-1216.

Lynne, B. 2015. Fungi ecosystems and global change. Pages 361-400 in: The Fungi. S. C. Watkinson, L. Boddy, and N. Money, eds. Elsevier Science, Waltham, MA.

Mueller, D., and Wise, K. A. 2012. Diseases of corn: Corn disease loss estimates from the United States and Ontario, Canada. Coop. Ext. Pub. No. BP-96-12W. Purdue Univ., West Lafayette, IN.

Mueller, D., and Wise, K. A. 2013. Diseases of corn: Corn disease loss estimates from the United States and Ontario, Canada. Coop. Ext. Pub. No. BP-96-13W. Purdue Univ., West Lafayette, IN.

Mueller, D., and Wise, K. A. 2014. Diseases of corn: Corn disease loss estimates from the United States and Ontario, Canada. Coop. Ext. Pub. No. BP-96-14W. Purdue Univ., West Lafayette, IN.

Payne, G. A., and Waldron, J. K. 1983. Overwintering and spore release of Cercospora zeae-maydis in corn debris in North Carolina. Plant Dis. 67: 87-89.

Pereyra, S. A., Dill-Macky, R., and Sims, A. L. 2004. Survival and inoculum production of Gibberella zeae in wheat residue. Plant Dis. 88:724-730.

Romero, M. P., and Wise, K. A. 2015. Development of molecular assays for detection of Stenocarpella maydis and Stenocarpella macrospora in corn. Plant Dis. 99:761-769.

Romero Luna, M. P. 2012. Managing Diplodia ear rot in corn: Short and longterm solutions. M.S. thesis. Botany and Plant Pathol. Dept., Purdue Univ., West Lafayette, IN.

Romero Luna, M. P. 2016. Stenocarpella maydis: Identification, management, and population diversity. Ph.D. diss. Botany and Plant Pathol. Dept., Purdue Univ., West Lafayette, IN.

Romero Luna, M. P., and Wise, K. A. 2015. Timing and efficacy of fungicide applications for Diplodia ear rot management in corn. Plant Health Prog. 16: 123-131.

Rossouw, J. D., Pretorius, Z. A., Silva, H. D., and Lamkey, K. R. 2009. Breeding for resistance to Stenocarpella ear rot in maize. Plant Breed. Rev. 31:223-246.

Scheeringa, K., and Mangan, M. R. 2015. Monthly weather reports. Indiana State Climate Office, Purdue Univ., West Lafayette, IN. http://www.iclimate. org/weather-summaries.

Schwietzke, S., Kim, Y., Ximenes, E., Mosier, N., and Ladisch, M. 2009. Ethanol production from maize. Pages 347-364 in: Molecular Genetic Approaches to Maize Improvement. A. L. Kriz, and B. A. Larkins, eds. Springer, Berlin.

Starzyk, M. J. 1976. Effect of temperature and light on sporulation of Diplodia zeae. Microbios Lett. 1:143-147.

Sutton, B. C., and Waterston, J. M. 1966. Diplodia maydis. CMI Descriptions of Pathogenic Fungi and Bacteria. Set 9. No. 84. CAB International, Wallingford, UK.

Thomison, P., Lipps, P., Hammond, R., Mullen, R., and Eisley, B. 2005. Ohio Agronomy Guide. Coop. Ext. Bull. 475-05. The Ohio State University, Columbu, OH .

Ullstrup, A. J. 1970. Methods for inoculating corn ears with Gibberella zeae and Diplodia maydis. Plant Dis. Rep. 54:658-662.

Van Etten, J. L., and Freer, S. N. 1978. Simple procedure for disruption of fungal spores. Appl. Environ. Microbiol. 35:622.

White, D. G. 1999. Page 44-45 in: Compendium of Corn Diseases, 3rd Ed. American Phytopathological Society, St. Paul, MN. 